\title{
Influence of five plant dried leaf powders on eggplant plants infected with Meloidogyne incognita under greenhouse conditions
}

\author{
Gad, S. B.* and Sergany M. I** \\ * Nematology Res. Unit, Agric. Zool. Dept, Fac. of Agric., Mansoura Univ. Mansoura, DK., Egypt. \\ ** Pesticides Dept. Fac. of Agric., Mansoura Univ. Dk. Egypt. \\ Corresponding author: Samir Borham Gad Borham \\ E-mail: samirborham@mans.edu.eg
}

\begin{abstract}
A greenhouse trail was conducted to study the influence of five plant dried leaf powders i.e. cabbage, sorrel, spinach, rocket and tomato in comparing with oxamyl on root-knot nematode $M$. incognita infecting eggplant under greenhouse conditions. All treatments showed remarkable increase in plant growth parameters as well as reduced nematode criteria. Cabbage dried leaf powder showed higher effectiveness of the tested botanical dried leaf powders and enhanced plant growth parameters with significant increase values. On the other hand, spinach dried leaf powder as soil amendments overwhelmed other treatments in suppressing nematode population in soil $(78.3 \%)$, root galling number $(87.0 \%)$, egg-masses $(91.5 \%)$ and eggs / one gram root $(91.5 \%)$ respectively. However, the least values of the same nematode criteria was achieved by sorrel treatment with values of $34.0,77.3,90.5$ and 89.3 respectively, comparing to nematode alone. The recorded results showed a potential properties of using such plant dried leaf powders as ecofriendly control method instead of chemical pesticides.
\end{abstract}

Keywords: Eggplant, Meloidogyne incognita, control, oxamyl, induced resistance, plant, powder.

\section{Introduction}

Root-knot nematodes (Meloidogyne spp.) are one of the most wide spread and damaging agricultural pests in the world causing an estimated US $\$ 100$ billion loss/ year worldwide (Oka et al., 2000). Root-knot nematodes are obligate parasites and very injurious plant pests for limiting the agricultural productivity. Most cultivated plant species are susceptible to root-knot nematode infection. In Egypt, root-knot nematodes, Meloidogyne spp. are becoming a real threat to almost all vegetable crops, especially in the newly reclaimed areas and they have been considered as limiting factors in crop production (Ibrahim et al., 1992). Because of the lack of resistance in plants to most species of root-knot nematode as well as the environmental restrictions on nematicidal use for controlling plant parasitic nematodes; biological control and other eco-friendly control trial have gained recently increasing interest. On the other hand, it has been suggested that the use 
of induced resistance in plants could offer a considerable potential for biological control (Deverall, 1995). A new strategy for adjusting plant parasitic nematodes is based on the activation of the plant's own defense system via various biotic and abiotic agents. It was very important to found naturally nematicides which may be safely to human health and environmental conditions. Using plant leaves to reduce phytonematodes as soil amendments had been studied by many researchers (Adegbite and Adesiyanm, 2005; Abbas et al., 2009 and Wani, 2006). There is no literature review demonstrated the efficacy of certain plant dried leaf powders i.e. cabbage, sorrel, spinach, rocket and tomato plants against plant parasitic nematodes. Therefore, the objective of present investigation was carried out to study the adequacy of the previous plant dried leaf powders in comparison with oxamyl as a nematicides on plant growth response of tomato plants infecting with $M$. incognita under greenhouse conditions.

\section{Materials and Methods}

\section{Source of nematodes:}

Second stage juveniles (J2) of Meloidogyne incognita (Kofoid \& White) Chitwood, were obtained from a pure culture of $M$. incognita that was initiated by a single eggmass propagated on coleus plants, Coleus blumei in the greenhouse of Nematology Research Unit, (NERU) Agricultural Zoology Department, Faculty of Agriculture, Mansoura University, Egypt, where this work was carried-out. Second stage juveniles (J2) were extracted from soil of coleus plants by sieving and modified Baermann technique (Goodey, 1957) counted in a Hawksely counting slide under x 10 magnification then calculated for each $1 \mathrm{ml}$ of the nematode suspension and recorded for preparing nematode inoculation of this work.

\section{Nematicide:}

Oxamyl (Vydate) 24\% L. Methyl-N'N'- dimethyl-N [(methyl) carbamoyl-oxy]-1thioxamidate, which was used at the rate of $0.3 \mathrm{ml} /$ plant.

\section{Prepare plant dried leaf powders:}

Fresh leaves of certain tested plants i.e. Cabbage Brassica oleracea, Sorrel Rumex vesicarius, Spinach Spinacia oleracea, Rocket Eruca Sativa, and tomato Solanum lycopersicum were collected from farmers, Dakahlia governorate and botany indentified then sun dried and were separately ground to fine powders in a grinder and separately added at the rate of $5 \mathrm{~g} /$ plant $/$ pot according to the design of the experiment.

\section{Greenhouse experiment:}

A pot trial was set-up to study the effect of five plants dried leaf powders i.e. (Cabbage) Brassica Oleracea, (Sorrel plant) Rumex vesicarius, (Spinach) Spinacia oleracea, (Rocket) Eruca Sativa (tomato) Solanum lycopersicum in comparing with oxamyl at the recommended dose on root-knot nematode $M$. incognita infecting 
eggplant plant cv. Melana (Solanum melongena L.) under greenhouse conditions $\left(25 \pm 2^{\circ} \mathrm{C}\right)$. Sixty four plastic pots $(10 \mathrm{~cm}$-diam). containing $900 \mathrm{~g}$ steam sterilized sand loamy soil $(1: 1, \mathrm{v}: \mathrm{v})$ with one 30 day-old sterilized eggplant seedlings each were used in this study. One week after eggplant seedlings transplanting, $3000 \mathrm{~J}_{2}$ of $M$. incognita were inoculated to fifty six seedlings each and eight non inoculated were used as control. One week later, treatments were added to eight seedlings each and mixed with soil, while eight seedlings with nematode received oxamyl at the rate of $0.3 \mathrm{ml} /$ plant. Another eight seedlings (pots) with nematode only were left without any treatment. Treatments were as follows:

1. $\mathrm{N}+$ cabbage powder $(5 \mathrm{~g} / \mathrm{pot})$,

2. $\mathrm{N}+$ Sorrel powder $(5 \mathrm{~g} / \mathrm{pot})$,

3. $\mathrm{N}+$ Spinach powder (5g/pot),

4. $\mathrm{N}+$ Rocket powder $(5 \mathrm{~g} / \mathrm{pot})$,

5. $\mathrm{N}+$ tomato powder $(5 \mathrm{~g} / \mathrm{pot})$,

6. N + Oxamyl $(0.3 \mathrm{ml} /$ plant $)$,

7. Nematode alone and

8. Plant free of nematode and any treatments.

Each treatment was replicated eight times. Plastic pots were arranged in a randomized complete block design and irrigated with tap water as needed. Plants were harvested 45 days after nematode inoculation, and plant growth criteria i.e. shoot and root lengths; and fresh weights, as well as shoot dry weights were determined and recorded. Number of $M$. incognita $\left(\mathrm{J}_{2}\right)$ in $250 \mathrm{~g}$. of soil/pot were extracted by sieving and modified Baermann technique (Goodey, 1957) counted in a Hawksely counting slide under $\times 10$ magnification then calculated for each pot and recorded. Infected roots of each plant per treatment were washed with tap water, fixed in 4\% formalin for $24 \mathrm{hrs}$ and stained in 0.01 lactic acid-fuchsin (Byrd et al., 1983) and then examined for the number of galls, and egg-masses. Eggs were extracted from root system using $1.0 \%$ sodium hypochlorite (Hussey and Barker, 1973) and number of eggs/ one gram root was recorded. The root gall index (RGI) and egg mass index (EI) were estimated according to the scale given by (Taylor and Sasser, 1978) as follows: $0=$ no galls or egg-masses, $1=1-2$ galls or eggmasses, $2=3-10$ galls or egg-masses, $3=11-30$ galls or egg-masses, $4=31-100$ galls or egg-masses and $5=$ more than 100 galls or egg-masses.

\section{Data analysis:}

The obtained data were subjected to ANOVA, followed by Duncan's multiple ranges to compare means (Duncan, 1955). All calculations were performed with COSTAT software. 


\section{Results and Discussion}

Data represented in Table (1) documented the response of eggplant plant to tested botanical plant dry powders under the stress of $M$. incognita in comparison with oxamyl as a nematicide under greenhouse conditions. All treatments showed remarkable increase in plant growth parameters in terms of plant length, plant fresh and dry weights with various degrees. It was evident that cabbage powder showed higher effectiveness of the tested botanical powders to enhance plant growth parameters and achieved significant increase values of plant length (81.2\%), total plant fresh weight $(60.1 \%)$ and shoot dry weight $(88.6 \%)$, followed by spinach leaves treatment with values of $62.3,36.6$ and $77.1 \%$ for the same plant growth criteria, respectively, comparing to nematode alone. (Table 1). Meanwhile, plant receiving the rocket and tomato dried leaf powders treatments showed considerable percentage increase values of plant length (50.0\%), total plant fresh weight $(33.9 \%)$ and shoot dry weight $(71.4 \%)$, respectively. However, plant treated by tomato or sorrel dried leaf powders gave the least percentage increase values of plant length (29.0 \&38.0\%), total plant fresh weight (27.9 \& 5.5\%), shoot dry weight (37.1\&37.1\%), respectively. Meanwhile, oxamyl as a systemic nematicide recorded moderately values in ameliorating plant growth values that averaged 42.4, 19.7 and $28.6 \%$ for plant length, total plant fresh weight and shoot dry weight, respectively, comparing to nematode alone.

Data presented in Table (2) reveal that all tested components showed protection performance in eggplant plant against nematode infection in terms of reduction percentage of nematode criteria on such host plant, It was clear that nematode reproduction were significantly affected by all tested treatments. Among the tested applications spinach leaves as soil amendments overwhelmed other treatments in suppressing nematode population in soil $(78.3 \%)$, root galling number (87.0\%), egg-masses (91.5\%) and eggs /one gram root $(91.5 \%)$, followed by tomato application with values of $76.8,87.0,90.5$ and $90.8 \%$ for the same nematode criteria, and then cabbage or rocket that gave the intermediate reduction values which were amounted to 72.5 or 71.6 ; 86.2 or $82.5 \%$; 89.4 or $91.1 \%$ and 91.0 or $89.3 \%$ for nematode population in soil, number of galls, egg-masses and eggs / one gram root respectively, comparing to nematode alone (Table 2). However, the least values of the same nematode criteria was achieved by sorrel treatment with values of $34.0,77.3,90.5$ and 89.3 for number of nematode in soil, number of galls, eggmasses and eggs / one gram root respectively, comparing to nematode alone.

In the present study, five botanical dried leaf powders i.e. sorrel, spinach, cabbage, rocket and tomato showed nematicidal properties against the target pest, $M$. incognita infecting eggplant as well as all tested materials significantly caused ameliorating plant growth and suppressed nematode criteria as well. 
Table (1): Plant growth response of eggplant plant cv. Melana infected with $M$. incognita under the stress of tested five botanical dried-leaf powders under greenhouse conditions.

\begin{tabular}{|c|c|c|c|c|c|c|c|c|c|c|}
\hline \multirow{2}{*}{$\begin{array}{c}\text { Treatments } \\
\text { (plant dried-leaf } \\
\text { powders) }\end{array}$} & \multicolumn{2}{|c|}{ Length (cm) } & \multirow{2}{*}{ Total } & \multirow{2}{*}{$\begin{array}{c}\text { Increase } \\
\%\end{array}$} & \multicolumn{2}{|c|}{ Fresh weight (g) } & \multirow{2}{*}{$\begin{array}{c}\text { Total F.W } \\
\text { (g) }\end{array}$} & \multirow{2}{*}{$\begin{array}{c}\text { Increase } \\
\%\end{array}$} & \multirow{2}{*}{$\begin{array}{c}\text { Shoot D.W } \\
\text { (g) }\end{array}$} & \multirow{2}{*}{$\begin{array}{c}\text { Increase } \\
\%\end{array}$} \\
\hline & Shoot & Root & & & Shoot & Root & & & & \\
\hline Cabbage & 18.1 $\pm 4.1 \mathrm{ab}$ & $32.5 \pm 2.6 a$ & $50.6 \pm 4.9 a$ & 81.2 & $17.0 \pm 5.2 \mathrm{bc}$ & $12.3 \pm 7.0 \mathrm{a}$ & $29.3 \pm 11.4 a$ & 60.1 & $6.6 \pm 2.0 \mathrm{a}$ & 88.6 \\
\hline Sorrel & $14.0 \pm 4.4 \mathrm{bc}$ & $24.1 \pm 6.4 \mathrm{abcd}$ & $38.1 \pm 3.7 b$ & 38.0 & $15.0 \pm 5.2 b c$ & $4.3 \pm 0.7 b$ & $19.3 \pm 4.9 a b$ & 5.5 & $4.8 \pm 1.8 a$ & 37.1 \\
\hline Spinach & $14.7 \pm 4.1 \mathrm{bc}$ & $30.0 \pm 2.7 a b$ & $44.8 \pm 4.9 a b$ & 62.3 & $20.1 \pm 7.7 a b$ & $4.9 \pm 2.2 b$ & $25.0 \pm 8.4 a$ & 36.6 & $6.2 \pm 1.6 a$ & 77.1 \\
\hline Tomato & $13.3 \pm 4.9 \mathrm{bc}$ & $22.4 \pm 8.1 \mathrm{bcd}$ & $35.6 \pm 8.2 b$ & 29.0 & $18.0 \pm 4.7 a b c$ & $5.4 \pm 2.6 \mathrm{~b}$ & $23.4 \pm 5.4 a b$ & 27.9 & $4.8 \pm 1.8 a$ & 37.1 \\
\hline Rocket & $13.3 \pm 4.9 b c$ & $28.1 \pm 5.0 \mathrm{abc}$ & $41.4 \pm 5.0 a b$ & 50.0 & $18.3 \pm 2.5 a b c$ & $6.3 \pm 2.2 b$ & $24.5 \pm 3.6 a b$ & 33.9 & $6.0 \pm 2.4 a$ & 71.4 \\
\hline Oxamyl & $18.6 \pm 3.9 a b$ & $20.6 \pm 7.1 \mathrm{~cd}$ & $39.3 \pm 8.8 b$ & 42.4 & $16.6 \pm 1.8 b c$ & $5.3 \pm 1.8 b$ & $21.9 \pm 2.7 a b$ & 19.7 & $4.5 \pm 2.1 \mathrm{a}$ & 28.6 \\
\hline Nematode alone & $10.0 \pm 5.1 \mathrm{c}$ & $17.6 \pm 5.0 \mathrm{~d}$ & $27.6 \pm 9.9 c$ & ----- & $11.7 \pm 5.8 \mathrm{c}$ & $6.6 \pm 4.0 \mathrm{~b}$ & $18.3 \pm 8.6 b$ & ---- & $3.5 \pm 1.4 a$ & --- \\
\hline Untreated plants & $21.0 \pm 4.5 \mathrm{a}$ & $24.0 \pm 6.6 \mathrm{bcd}$ & $45.0 \pm 7.8 \mathrm{ab}$ & 63.0 & $24.4 \pm 3.1 a$ & $4.1 \pm 1.2 b$ & $28.5 \pm 2.4 a$ & 55.7 & $5.6 \pm 2.7 a$ & 60.0 \\
\hline L.S.D 0.05 & 4.49 & 6.15 & 6.99 & - & 4.8 & 3.32 & 6.66 & - & 2.03 & - \\
\hline$F$ & 5.09 & 6.007 & 7.93 & - & 4.60 & 5.13 & 2.82 & - & 2.14 & - \\
\hline$P$ & .0002 & .0001 & .00001 & - & .0004 & .0001 & .0136 & - & .0534 & - \\
\hline
\end{tabular}

$\mathrm{N}=3000 \mathrm{~J} 2$ of $M$. incognita.

* Each value is the mean of eight replicates.

* Means in each column followed by the same letters(s) did not differ at $p<0.05$ according to Duncan's multiple range tests. 
Table (2): Response of Meloidogyne incognita infecting eggplant plant cv. Melana as affected by tested five plants dried leaf powders under greenhouse conditions.

\begin{tabular}{|c|c|c|c|c|c|c|c|c|c|c|}
\hline $\begin{array}{c}\text { Treatments } \\
\text { (dried-leaf } \\
\text { powders) }\end{array}$ & N. Soil & $\begin{array}{c}\text { Reduction } \\
\%\end{array}$ & No. of galls & $\begin{array}{c}\text { Reduction } \\
\% \\
\end{array}$ & RGI & $\begin{array}{c}\text { No. of } \\
\text { eggmasses }\end{array}$ & $\begin{array}{c}\text { Reduction } \\
\% \\
\end{array}$ & E. I & $\begin{array}{c}\text { Eggs/ } \\
1 \text { gram root }\end{array}$ & $\begin{array}{c}\text { Reduction } \\
\% \\
\end{array}$ \\
\hline Cabbage & $1971.9 \pm 614.2 c$ & 72.5 & $25.6 \pm 15.16 b$ & 86.2 & $3.2 \pm 0.7 \mathrm{bc}$ & $6.7 \pm 3.0 \mathrm{~b}$ & 89.4 & $1.9 \pm 0.4 b$ & $328.0 \pm 136.6 \mathrm{~b}$ & 91.0 \\
\hline Sorrel & $4732.75 \pm 463.5 \mathrm{~b}$ & 34.0 & $42.2 \pm 18.8 b$ & 77.3 & $3.7 \pm 0.4 b$ & $6.0 \pm 2.61 b$ & 90.5 & $1.9 \pm 0.4 b$ & $335.5 \pm 130.7 b$ & 90.8 \\
\hline Spinach & $1559.3 \pm 283.5 \mathrm{c}$ & 78.3 & $24.1 \pm 16.9 b$ & 87.0 & $2.9 \pm 0.4 \mathrm{bc}$ & $5.6 \pm 2.7 b$ & 91.1 & $1.8 \pm 0.3 b$ & $309.3 \pm 82.6 b$ & 91.5 \\
\hline Tomato & $1663.75 \pm 1040.81 \mathrm{c}$ & 76.8 & $24.1 \pm 16.86 b$ & 87.0 & $2.9 \pm 0.35 \mathrm{c}$ & $6.0 \pm 2.6 \mathrm{~b}$ & 90.5 & $2.0 \pm 0 b$ & $335.5 \pm 130.7 b$ & 90.8 \\
\hline Rocket & $2040.4 \pm 490.6 c$ & 71.6 & $31.6 \pm 19.2 b$ & 82.5 & $3.4 \pm 0.5 \mathrm{bc}$ & $6.2 \pm 2.3 \mathrm{~b}$ & 90.2 & $2.0 \pm 0 \mathrm{~b}$ & $309.0 \pm 82.4 \mathrm{~b}$ & 91.5 \\
\hline Oxamyl & $1288.8 \pm 77.9 c$ & 82.0 & $15.4 \pm 4.4 b$ & 91.7 & $2.9 \pm 0.4 c$ & $5.9 \pm 2.4 b$ & 90.6 & $2.0 \pm 0 \mathrm{~b}$ & $391.3 \pm 85.9 b$ & 89.3 \\
\hline $\mathrm{N}$ alone & 7173.8 $\pm 1078.0 a$ & 0.0 & $186.0 \pm 74.3 a$ & 0.0 & $4.8 \pm 0.5 a$ & $63.0 \pm 19.5 a$ & 0.0 & $4.0 \pm 0 a$ & $3642.4 \pm 137.4 a$ & 0.0 \\
\hline L.S.D 0.05 & 637.25 & -- & 31.61 & -- & 0.47 & 7.79 & -- & 0.35 & 109.05 & -- \\
\hline $\mathrm{F}$ & 93.03 & -- & 30.05 & -- & 15.37 & 62.44 & -- & 40.9 & 1064.74 & -- \\
\hline $\mathrm{P}$ & .00001 & -- & .00001 & -- & .00001 & .00001 & -- & .00001 & .00001 & -- \\
\hline
\end{tabular}

${ }^{*} \mathrm{~N}=3000 \mathrm{~J} 2$ of $M$. incognita.

ox= oxamyl.

* Each value is the mean of eight replicates.

Means in each column followed by the same letters(s) did not differ at $p<0.05$ according to Duncan's multiple range tests. 
These materials seemed to have higher toxic action but not as much as oxamyl (nematicide) which overwhelmed in some cases all other tested treatments. Many reports in literature emphasized the role of plant powders in controlling plant parasitic nematode. The nematicidal activity of tested botanical components such as cabbage product is due mainly to their contents of glucosinolates and myrosinae located in different parts of the cell come into contact (Poulton and Moller, 1993). The enzymatic hydrolysis of glucosinolates may lead to the formation of bioactive volatile is othiocynates (Cole, 1976 and Fenwick et al., 1963). Obviously, isothiocynates are though to be the main components of the pest-pathogen-and weed-suppressive effects that observed after soil incorporation of brassica tissue (Kirkegaard and Sarwar, 1999) and their inhibitory effect on fungi, bacteria, insects and nematodes and weeds has been amply demonstrated in in-vitro experiments (Brown and Morra1997; Harvey, 2002 and Bello et al., 2004). These various tested materials may play a role in defense mechanisms of the tested host plants against involving the target nematodes. Tomato leaves could be useful as a biological control agent due to a strong antifungal activity against pathogenic fungi and indicating a defense response against plant pathogenic fungi (Kobayashi, 2012). The major chemical components of tomato leaves were sugars, mineral composition, organic acids, lycopene, total phenols and hydroxycinnamic acids (Suárez, et al., 2008). The chemical composition of Rumex vesicarius indicates that it is a good source of minerals, a moderate source of protein and ascorbic acid and high in oxalic acid as well as low in lipids and tocopherol (Alfawaz, 2004). $R$. vesicarius is a good source of bioactive compounds due to its content of various phytochemicals such as phenolic and antioxidant compounds (Beddou, et al., 2015). These various tested materials may play a role in defense mechanisms of tested host plants against the target nematodes. Antioxidants such as ascorbic acid(vitamin C) and oxalic acid are essential for plant defense to avoid damage from abiotic and biotic stress (Racchi, 2013). An increasing demand to environmentally acceptable alternative for traditional pesticides provides an important to search new bio-based strategies in crop protection. Employing induced resistance is one of such strategy, consisting of boosting the natural plant immunity against plant parasitic nematodes. Botanical plant parts have been a valuable source of biologically active compounds especially of used to protect plants from pests and diseases. Botanical inducer resistance can be combined with biopesticides, biological control agents, biostimulants and even chemical pesticides, which could result in reduced pesticide consumption (Burketova et al, 2015). The chemical elicitors such as salicylic acid affect production of phenolic compounds and activation of various defense-related enzymes in plants. Their introduction into agricultural practice could minimize the scope of chemical control (Thakur and Sohal, 2013). 


\section{Conclusion}

It could be concluded that tested botanical dried leaf powders showed nematicidal properties against $M$. incognita, which may considered as environmentally acceptable alternative for traditional pesticides in crop protection. These various tested materials may also play a role in defense mechanisms of tested host plants against the target nematodes. The topic need more applicable studies to prove these findings.

\section{References}

Abbas S., Dawar S., Tariq M. and Zaki M. J. (2009). Nematicidal activity of spices against Meloidogyne javanica (Treub) chitwood. Pak. J. Bot., 41(5): 2625-2632.

Adegbite A. A. and Adesiyan S. O. (2005). Root extracts of plants to control rootknot nematode on edible soybean. World Journal of Agricultural Sciences, 1:18-21.

Alfawaz M. A. (2004). Chemical composition of hummayd (Rumex vesicarius) grown in Saudi Arabia. Journal of Food Composition and Analysis 19(67):552-555.

Beddou F., Bekhechi C., Ksouri R.; Sari D. C. and Bekkara F. A. (2015). Potential assessment of Rumex vesicarius $\mathrm{L}$. as a source of natural antioxidants and bioactive compounds. J Food Sci Technol 52: 3549.

Bello A., López-Pérez J. A., García-Álvarez A., Sanz R. and Lacasa A. (2004). Biofumigation and nematode control in the Mediterranean region. In: Cook RC, Hunt DJ, editors. Nematology monographs and perspectives; Proceedings of the Fourth International Congress of Nematology; 8-13 June, 2002; Tenerife, Spain. Leiden and Boston: Brill; 2004. pp. 133-149.

Brown PD., and Morra M. J. (1997). Control of soil-borne plant pests using glucosinolate-containing plants. Adv. Agron. 61:167-231.

Burketova L., Trda L., Ott P. G. and Valentova O. (2015). Bio-based resistance inducers for sustainable plant protection against pathogens. Biotechnology Advances 33:994-1004.

Byrd D. W., Kirkpatrick T. and Barker K. (1983). An improved technique for clearing and staining plant tissues for detection of nematodes. J. Nematol., 15(3):142-143.

Cole R. A. (1976). Isothiocyanates, nitriles and thiocyanates as products of autolysis of glucosinolates in Cruciferae. Phytochemistry.;15:759-762.

Deverall B. J. (1995). Plant protection using natural defense systems of plants in: (Eds. Andrews, J. H. \& Tommerup, I. C.) Advances in plant pathol., (11), San Diego, USA, Academic Press, PP. 211-228.

Duncan D. B. (1955). Multiple range and multiple, F-test. Biometrics, 11:1-42. 
Fenwick G. R., Heaney R. K. and Mullin W. J. (1963). Glucosinolates and their breakdown products in food and food plants. In: Furia TE, editor. Critical Reviews in Food Science and Nutrition. Boca Raton: CRC Press;. pp. 123201.

Goodey J.B. (1957). Laboratory methods for work with plant and soil nematodes. Tech. Bull.No.2 Min. Agric. Fish Ed. London. pp.47.

Harvey S.G., Hannahan H. and Sams C. E. (2002). Indian mustard and allyl isothiocyanate inhibit Sclerotium rolfsii. J. American Society Horticultural Sci. 2002;127:27-31.

Hussey, R. S. and Barker, K. R. (1973). A comparison on methods of collecting inocula of Meloidogyne spp. including a new technique. Plant Dis. Reptr., 57: 1925-1928.

Ibrahim I. K. A., Reza M. A. and Khalil H. A. A. (1992). Reaction of fifteen Malvaceous plant cultivars to root-knot nematodes, Meloidogyne spp. J. Nematol. Medit. 10: 135-139.

Kirkegaard J. A. and Sarwar M. (1999). Glucosinolate profiles of Australian canola (Brassica napus annua L.) and Indian mustard (Brassica juncea L.) cultivars: implications for biofumigation. Aust. J. Agric. Res 50:315-324.

Kobayashi F., Ishida K., Ikeura H., Odake S. and Hayata Y. (2012) Application of Tomato (Solanum lycopersicum) Leaf Volatiles as Antifungal Agents against Plant Pathogenic Fungi. Journal of Agricultural Science, 4(8);231235.

Oka Y., Necar S., Putievesky E., Ravid V., Yaniv Z. and Spiegel Y. (2000). Nematicidal activity of essential oils and their components against the rootknot nematode. J. Phytopathol., 90(7): 710-715.

Poulton J. E. and Moller B. L. (1993). Glucosinolates. Methods in Plant Biochemistry. vol. 9. London: Academic Press;. pp. 209-237.

Racchi M. L. (2013). Antioxidant Defenses in Plants with Attention to Prunusand Citrus spp. Antioxidants, 2(4),340-369.

Suárez M. H., Pallarés J. R., Mesa D. R., Rodríguez E. R. and Romero C. D. (2008). Variation of the chemical composition of tomato cultivars (Lycopersicon esculentum Mill.) according to resistance against the tomato yellow leaf curl virus (TYLCV). J. Sci. Food Agric., 88: 1882-1891.

Taylor A. L. and Sasser J. N. (1978). Biology identification and control of root-knot nematode(Meloidogyne spp.) Raleigh: North Carolina state Univ. Graphics. Raleigh, NC. 111 pp.

Thakur M. and Sohal B. S. (2013). Role of elicitors in inducing resistance in plants against pathogen infection: A Review," ISRN Biochemistry, 10 pages

Wani A. H. (2006). Management of root-knot nematode, Meloidogyne incognita, on okra and lentil by soil amendment with oil cakes and leaves of different plants. Nematologia Mediterranea. 34 (1): 83-87. 
تأثير مسحوق الأوراق الجافة لخمسة نباتات على نبات الباذنجان المصاب بنيماتودا تعقد الجذور

$$
\begin{aligned}
& \text { "ميلدوجيني انكوجنيتا" تحت ظروف الصوبة الزراعية } \\
& \text { سمير برهام جاد*، محمد إبراهيم السرجاني } \\
& \text { * وحدة بحوث النيماتولوجي، قسم الحيوان الزراعي، كلية الزراعة، جامعة المنصورة. }
\end{aligned}
$$

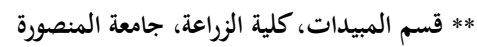

تم إجراء تجربة تحت ظروف الصوبة الزراعية لتقييم خمسة من المساحيق الجافة لأوراق

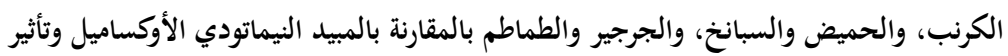

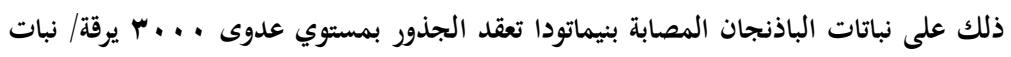

$$
\text { وقد أظهرت النتائج ما يلي: }
$$

ا-أظهرت جميع المعاملات ارتفاعًا ملحوظًا في المقاييس النباتية المختبرة بدرجات متفاوتة

$$
\text { وخفض المقاييس النيماتودية. }
$$

r-سجل مسحوق السبانخ المركز الأول في خفض أعداد النيماتودا في التربة (rی,

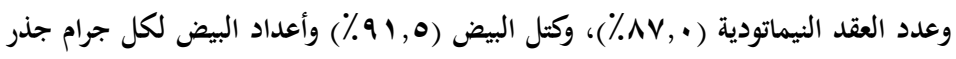

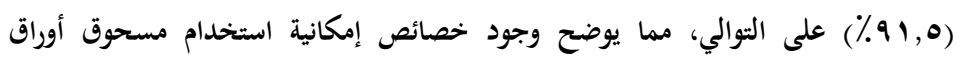

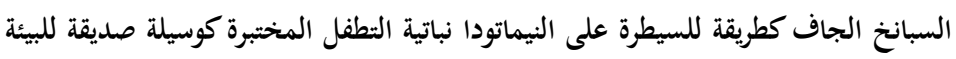

وبديلة للمبيدات.

ب-في حين حققت المعاملة بمسحوق أوراق الحميض الجافة أقل القيم في هذا السياق بقيم

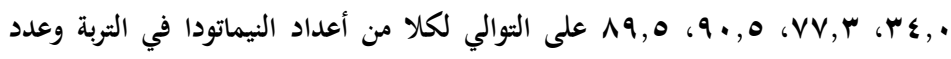

العقد النيماتودية وكتل البيض وأعداد البيض في واحد جم جذر هلى الهولي لهن التوالي. 